\title{
Optimal Ripeness Stage for Processing 'Kent' Mangoes into Fresh-cut Slices
}

\author{
Sharon Dea ${ }^{1}$, Jeffrey K. Brecht ${ }^{1,6}$, \\ Maria Cecilia do Nascimento Nunes ${ }^{2,4}$, and Elizabeth A. Baldwin ${ }^{3,5}$
}

ADDITIONAL INDEX WORDS. visual quality, compositional quality, aroma volatiles

Summary. The optimal ripeness stage for processing and marketing fresh-cut mangoes (Mangifera indica 'Kent') with best quality and maximum shelf life was determined. The initial ripeness stage selection was based on whole fruit firmness because this quality attribute was more reliable in predicting fresh-cut shelf life than flesh color or soluble solids content (SSC). Overall, the visual quality deteriorated differently and at different rates among ripeness stages. The shelf life, based on subjective visual evaluation, was 10,7 , and 5 days for ripeness stages corresponding to an average flesh firmness of 35, 30, and $25 \mathrm{~N}$, respectively, and was mainly limited by desiccation and development of off-odor for the two firmer ripeness stages or symptoms of edge tissue damage and spoilage for the least firm stage. The slices from fruit with the highest initial firmness remained firmer during storage, had the lowest $\mathrm{pH}$ and SSC to titratable acidity (TA) ratio, and had the highest contents of volatile ketones and esters. The softest slices had the highest $\mathrm{pH}$, SSC:TA ratio, and total ascorbic acid (TAA) content, as well as the lowest TA and highest volatile aldehyde and alcohol contents. Intermediate firmness slices had intermediate $\mathrm{pH}, \mathrm{SSC}$ :TA ratio, color, and TAA content. Also, they had less volatile alcohols and aldehydes than slices from riper fruit but had similar content of esters as slices from the less ripe fruit. Therefore, based on the results from this study, an initial firmness of $30 \mathrm{~N}$ is recommended to process mangoes into fresh-cut slices because it assures the best quality and maximum shelf life based on textural, visual, and compositional attributes.

M aximum shelf life and best eating quality are extremely important attributes for successful commercialization of fresh-cut fruits, but both are greatly influenced by the initial ripeness stage of the fruit as well as by the cutting procedures (Allong et al., 2001; Gorny et al., 1999). Within the fresh-cut industry, the establishment of the end of shelf life has been largely based on appearance while neglecting flavor and texture (Beaulieu and Gorny, 2004). To maximize shelf life, firmer, less ripe fruit are usually chosen for processing because of their better firmness retention and minimal change in appearance during handling rather than softer, riper fruit (Hodges and Toivonen, 2008). However, less ripe fruit have

\footnotetext{
${ }^{1}$ Horticultural Sciences Department, University of Florida, Gainesville, FL 32611

${ }^{2}$ Food Science and Human Nutrition Department, University of Florida, Gainesville, FL 32611

${ }^{3}$ USDA-ARS Citrus and Subtropical Products Laboratory, Winter Haven, FL 33881

${ }^{4}$ Current address: Department of Cell Biology, Microbiology and Molecular Biology, University of South Florida, Tampa, FL 33620

${ }^{5}$ Current address: USDA-ARS Horticultural Research Laboratory, Fort Pierce, FL 34945

${ }^{6}$ Corresponding author. E-mail: jkbrecht@ufl.edu.
}

normally not attained the optimal aroma, sweetness, texture, and color that are appealing to the consumer, which can be detrimental for the commercialization of a relatively unfamiliar tropical fresh-cut fruit such as mango.

Because both physiological and metabolic activities change during ripening, fruit of different ripeness stages respond differently to peeling and slicing (Allong et al., 2001). Several studies have shown that the more advanced the stage of ripeness, the more susceptible the fruit is to wounding, hence to fresh-cut processing
(Beirão-da-Costa et al., 2006; Brecht, 1995; Gorny et al., 2000; SolivaFortuny and Martín-Belloso, 2003; Watada and Qi, 1999). Moreover, during ripening, changes in the aroma volatile profile also occur. For example, in 'Palmer' and 'Keitt' mangoes, terpenes were present in higher concentrations in firm-ripe fruit compared with soft-ripe fruit, which in turn had higher contents of esters and alcohols, mainly ethanol (Beaulieu and Lea, 2003).

Consumer buying decisions are mostly based on the appearance and freshness of the fresh-cut fruit product at the time of purchase. Recurring purchases, however, depend on consumer satisfaction in terms of the fresh-cut product's texture and flavor (Rico et al., 2007). Therefore, selection of a cultivar with inherently excellent quality potential and processing it at the optimal ripeness stage for fresh-cut processing, which should be based on appearance, sensory, and compositional quality, are key decisions for successful fresh-cut fruit product marketability.

Fruit firmness, peel color, and SSC frequently are used as criteria to measure ripeness of mango for freshcut processing (Allong et al., 2000; Beaulieu and Lea, 2003; Gil et al., 2006; González-Aguilar et al., 2007; Rivera-López et al., 2005; Tovar et al., 2001). However, a wide range of physiological changes affecting the eating quality occur during mango ripening. For example, the change in the relative sweetness (sugars) and tartness (acids) of the fruit during ripening is an important flavor quality attribute for mango (Brecht et al., 2004). The ratio of sugars to acids is normally considered a good indicator of sweetness perception by the

\begin{tabular}{llll}
\hline $\begin{array}{l}\text { Units } \\
\begin{array}{l}\text { To convert U.S. to SI, } \\
\text { multiply by }\end{array}\end{array}$ & U.S. unit & SI unit & $\begin{array}{l}\text { To convert SI to U.S., } \\
\text { multiply by }\end{array}$ \\
\hline 10 & $\%$ & $\mathrm{~g} \cdot \mathrm{kg}^{-1}$ & 0.1 \\
29.5735 & $\mathrm{fl} \mathrm{oz}$ & $\mathrm{mL}$ & 0.0338 \\
0.3048 & $\mathrm{ft}$ & $\mathrm{m}$ & 3.2808 \\
3.7854 & $\mathrm{gal}$ & $\mathrm{L}$ & 0.2642 \\
2.54 & inch(es) & $\mathrm{cm}$ & 0.3937 \\
25.4 & inch(es) & $\mathrm{mm}$ & 0.0394 \\
0.4536 & $\mathrm{lb}$ & $\mathrm{kg}$ & 2.2046 \\
4.4482 & $\mathrm{lbf}$ & $\mathrm{N}$ & 0.2248 \\
1 & $\mathrm{micron}$ & $\mu \mathrm{m}$ & 1 \\
28.3495 & $\mathrm{oz}$ & $\mathrm{g}$ & 0.0353 \\
1 & $\mathrm{ppm}$ & $\mathrm{mg} \cdot \mathrm{L}^{-1}$ & 1 \\
1 & $\mathrm{ppm}$ & $\mu \mathrm{L} \cdot \mathrm{L}^{-1}$ & 1 \\
$\left({ }^{\circ} \mathrm{F}-32\right) \div 1.8$ & ${ }^{\circ} \mathrm{F}$ & ${ }^{\circ} \mathrm{C}$ & $\left({ }^{\circ} \mathrm{C} \times 1.8\right)+32$ \\
& & &
\end{tabular}


consumer, for which the higher the ratio, the sweeter the product is perceived to be. The aim of this study was to determine the optimal ripeness stage for processing 'Kent' mango fruit into a high-quality fresh-cut product with maximum shelf life based on retention of acceptable appearance, subjective visual and aroma quality, and composition.

\section{Materials and methods}

FRUIT SOURCE AND INITIAL SELECTION. This study was conducted twice (Expts. 1 and 2) during the Peruvian 'Kent' mango season (Jan.Feb. 2008). For each experiment, 210 'Kent' mangoes, size 9 (Expt. 1) or 8 (Expt. 2), were bought from a distribution center in Gainesville, FL (Expt. 1), or received directly from a wholesaler in Miami and shipped via refrigerated truck to the Postharvest Laboratory at the University of Florida in Gainesville (Expt. 2).

Upon reception, all mangoes were stored at $20^{\circ} \mathrm{C}$ and the firmness of a subsample of fruit was measured daily until the firmness distribution of 40 fruit randomly sampled from the lot reached a mean of $\approx 35 \mathrm{~N}$ (ripeness stage $\mathrm{A}$ ), $30 \mathrm{~N}$ (ripeness stage $\mathrm{B}$ ), or $25 \mathrm{~N}$ (ripeness stage C) (Fig. 1). The whole fruit firmness was measured nondestructively using a Universal Testing Instrument (model 4411; Instron, Norwood, MA) fitted with a flat plate probe $(5 \mathrm{~cm}$ diameter $)$ and equipped with a $50-\mathrm{kg}$ load cell to simulate subjective evaluation of firmness accomplished by squeezing a fruit in the hand. After establishing zero force contact between the probe and the equatorial region of the fruit, the probe was driven with a crosshead speed of $0.8 \mathrm{~mm} \cdot \mathrm{s}^{-1}$ and the force was recorded at $2.5 \mathrm{~mm}$ deformation. This method of measuring firmness was previously determined by us not to result in damage to the fruit as indicated by lack of elevated respiration and ethylene production (data not shown).

When the 40 randomly sampled mangoes reached one of the desired firmness values $(35,30$, or $25 \mathrm{~N}$ for ripeness stages $\mathrm{A}, \mathrm{B}$, or $\mathrm{C}$, respectively), a total of 80 mangoes were randomly sampled from the ripening room, and a number was assigned to each mango for further selection. Firmness of all 80 fruit was initially measured following the same procedure described above.
Then, a 5.0-mm-deep slice was excised from the equatorial side of the mango using a mandolin slicer to measure the flesh color using a reflectance colorimeter (CR 200b; Minolta, Ramsey, NJ) and subsequently to measure the total SSC of the juice from the slice using a digital refractometer $\left(0\right.$ to $45^{\circ}$ Brix, Palette PR-101; Atago, Tokyo, Japan).

From the 80 -fruit sample, 36 mangoes were selected with comparable firmness values that were nearest to the 80 -fruit sample mean, as determined by the normal distribution plot using JMP ${ }^{\circledR} 7.0$ (SAS Institute,
Cary, NC). Figure 2 illustrates the selection process of the fruit designated as ripeness stage A in Expt. 2. This procedure resulted in three distinct ripeness stage samples (i.e., without overlap). As illustrated in Fig. 2 and also observed for all other fruit samples, there was much less fruitto-fruit variability in SSC and flesh color than for firmness, which made firmness the best criteria to use to obtain distinct ripeness stage samples. After selection of the 36-fruit subsample for each ripeness stage, those fruit were stored overnight at $5{ }^{\circ} \mathrm{C}$ and processed into fresh-cut

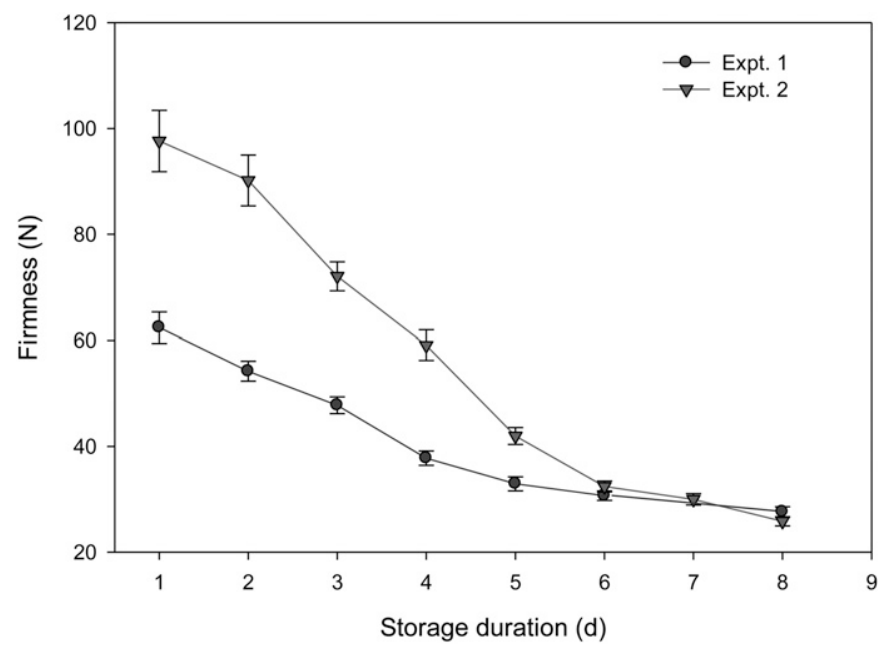

Fig. 1. Changes in the firmness of whole 'Kent' mango fruit during ripening at $20{ }^{\circ} \mathrm{C}\left(68.0{ }^{\circ} \mathrm{F}\right)$ for Expts. 1 and 2 . Vertical lines at data points represent \pm SD for $n=40 ; 1 \mathrm{~N}=0.2248 \mathrm{lbf}$.

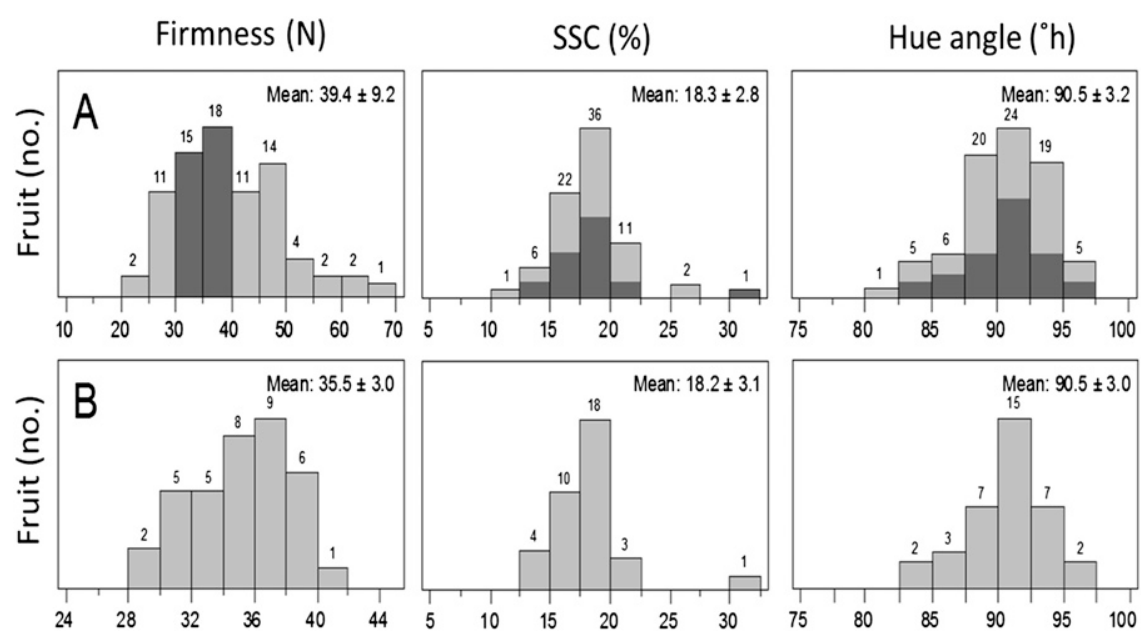

Fig. 2. Initial fruit selections for ripeness stage A (Expt. 2). (A) Distribution of firmness, soluble solids content (SSC), and hue angle values of 80 mangoes after ripening at $20^{\circ} \mathrm{C}\left(68.0^{\circ} \mathrm{F}\right)$. The shaded zone indicates mangoes with targeted firmness $(30$ to $40 \mathrm{~N})$ and their corresponding SSC and hue angle values. (B) Distribution of firmness, SSC, and hue angle of the 36 fruit selected from (A) for fresh-cut processing. Mean values are \pm SD for either 80 (A) or 36 (B) fruit; $1 \mathrm{~N}=0.2248$ lbf. 


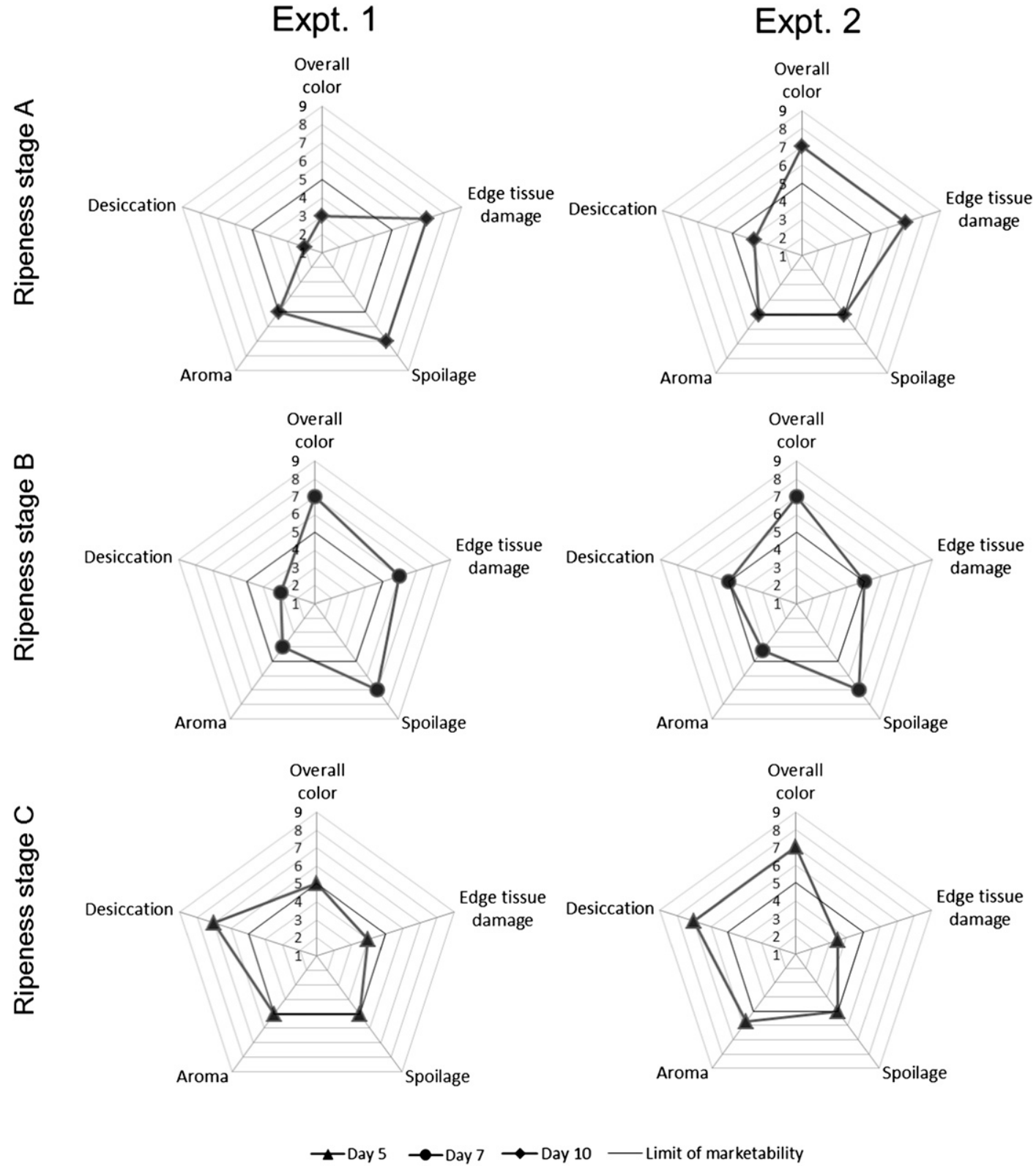

Fig. 3. Subjective quality scores of fresh-cut 'Kent' mango slices at the end of the shelf life for each ripeness stage (A, B, and C) after storage at $5{ }^{\circ} \mathrm{C}\left(41.0{ }^{\circ} \mathrm{F}\right)$; where 9 = excellent; 7 = very good; 5 = good, limit of marketability; $3=$ fair, absolute limit for household use with trimming, loss, or both; 1 = poor, inedible. Note that for spoilage and edge tissue damage, $9=$ no deterioration and so on. Rating of $\mathbf{5}$ is the minimum subjective score for marketing any product.

slices the next morning. The remaining 44 fruit from each original 80 fruit sample were discarded. The same process was repeated until the three desired ripeness stages were obtained.

FRESH-CUT PROCESSING. Before being peeled, the mangoes selected for processing received a 3 -min, 100-ppm chlorinated $5{ }^{\circ} \mathrm{C}$ water bath, adjusted to $\mathrm{pH} 7$ with $2 \mathrm{~N}$ citric acid solution. After peeling and before being drained and cut into slices, the mangoes were submerged in a fresh 100 -ppm chlorinated $5^{\circ} \mathrm{C}$ water bath at $\mathrm{pH} 7$. Each mango for fresh-cut processing was halved and cut into eight slices. All of the slices from the 36-fruit sample of appropriate firmness were pooled together before being randomly distributed into containers made of polyethylene terephthalate. The leak-free snap-on cover had a $15-\mathrm{mm}$-diameter hole that was plugged with a sterile cotton ball to assure both good air circulation and avoidance of microbial contamination. For each sample, eight random slices per container and 24 containers per treatment were stored at $5{ }^{\circ} \mathrm{C}$ for $10 \mathrm{~d}$.
SubJeCtive QuALITY EVALUATION. The sensory quality of four, eightslice samples of fresh-cut mangoes per ripeness stage were assessed by trained judges after $0,2,5,7$, and $10 \mathrm{~d}$ of storage at $5{ }^{\circ} \mathrm{C}$ using nine-point rating scales previously developed for evaluating fresh-cut mango slices for overall color, edge tissue damage, spoilage, aroma, and desiccation (Beaulieu and Lea, 2003). The scores generally correspond to quality as follows: $9=$ excellent; $7=$ very good; 5 = good; 3 = fair, absolute limit for household use with trimming, loss, or both; 
$1=$ poor, inedible. Note that for spoilage and edge tissue damage, $9=$ no deterioration and so on $[\mathrm{de}-$ tailed descriptions of the rating criteria can be found in Beaulieu and Lea (2003)]. All visual evaluations were performed by the same trained person. The limit of marketability of the fresh-cut mango samples was established when one or more of the quality attributes evaluated reached a subjective score of 5 . Although at this limit the fresh-cut mango slices were considered unsuitable for retail sale, they could still be considered edible with partial trimming, depending on a consumer's preferences.

RESPiration RATE MEASUREMENTS. Four containers of fresh-cut mango of each ripeness stage were individually sealed for $\mathrm{l}$ to $2 \mathrm{~h}$ in 2 -L plastic containers before sampling for respiration rate (RR) measurements. Samples $(0.5 \mathrm{~mL})$ of the headspace were withdrawn and carbon dioxide $\left(\mathrm{CO}_{2}\right)$ levels were analyzed using a gas chromatograph [GC (series 580; Gow-Mac Instrument Co., Bethlehem, PA)] equipped with a thermal conductivity detector and a $1.2 \mathrm{~m} \times$ $3.18 \mathrm{~mm}$ Porapak Q column [particle size 149-177 $\mu \mathrm{m}$ (80/100 mesh); Waters, Milford, MA].The carrier gas (helium) flow rate was $0.5 \mathrm{~mL} \cdot \mathrm{s}^{-1}$. The detector and injector were operated under ambient conditions $\left(23^{\circ} \mathrm{C}\right)$ and the oven temperature was set at $40{ }^{\circ} \mathrm{C}$. Respiration rate was expressed as $\mathrm{CO}_{2}$ production $\left(\mu \mathrm{g} \cdot \mathrm{kg}^{-1} \cdot \mathrm{s}^{-1}\right)$ and was quantified using a certified standard gas mixture containing $1.02 \%$ $\mathrm{CO}_{2}$. Respiration rate was measured at $5{ }^{\circ} \mathrm{C}$ using the same samples stored at $5{ }^{\circ} \mathrm{C}$ for $0,2,5,7$, and $10 \mathrm{~d}$.

Conductivity analysisEleCtrolyte Leakage. Twelve mesocarp tissue plugs $(5 \mathrm{~mm}$ diameter $x$ $10 \mathrm{~mm}$ length) were excised from the eight fresh-cut slices per sample using a No. 5 brass cork borer. The mesocarp plugs were cleaned of damaged cells by rinsing gently with deionized water and were incubated at room temperature for $3 \mathrm{~h}$ in a $30 \mathrm{~mL}$ solution of $0.7 \mathrm{~mol} \cdot \mathrm{L}^{-1}$ isotonic mannitol in water. The electrical conductivity of the solutions was measured before and after incubation using a conductivity instrument (YSI, Yellow Springs, $\mathrm{OH}$ ). Total electrolytes were determined after freezing at $-20{ }^{\circ} \mathrm{C}$, thawing, and rewarming to room temperature. Three measurements per sample were taken. Electrolyte leakage (EL) was expressed as a percent of the conductivity of total tissue electrolytes.

Slice firmness evaluation. Firmness of fresh-cut slices was measured using a Universal Testing Instrument (model 4411, Instron) fitted with a $\mathrm{l}-\mathrm{cm}$-diameter convex probe and equipped with a $50-\mathrm{kg}$ load cell. After establishing zero force contact between the probe and the largest flat side of each slice, the probe was driven with a crosshead speed of $0.8 \mathrm{~mm} \cdot \mathrm{s}^{-1}$. The force was recorded at $2.5 \mathrm{~mm}$ deformation. The measurements were made on the cut surface of four freshcut slices per sample. The results were displayed by the instrument and reported in Newtons.

Flesh COLOR MEASUREMENTS. Superficial flesh color measurements $\left(L^{*}, a^{*}, b^{*}\right)$ were made with the Minolta reflectance colorimeter on the cut surface of 10 mango slices from four containers per treatment. Numerical values of $a^{*}$ and $b^{*}$ were converted into hue angle $\left(\mathrm{h}^{\circ}=\right.$ $\left.\tan ^{-1} b^{*} / a^{*}\right)$ (Francis, 1980).

Compositional anAlysis. Samples destined for compositional analysis were homogenized in a blender and either frozen at $-20^{\circ} \mathrm{C}$ immediately in air-tight, zipper-lock, plastic freezer bags and kept at $-20{ }^{\circ} \mathrm{C}$ until $\mathrm{pH}$ and TA were measured (two to three months) or further processed immediately as described below for volatile and ascorbic acid analyses before freezing.

Individual frozen sample replicates were thawed before $\mathrm{pH}$ and TA analyses, and a $50 \mathrm{-g}$ aliquot of the tissue slurry was centrifuged at $17,600 g_{\mathrm{n}}$ for $25 \mathrm{~min}$. The clear juice was decanted from the centrifuge tubes and the $\mathrm{pH}$ and TA were determined using an automatic titrator (719 S Titrino; Metrohm Ion Analysis, Herisau, Switzerland). Aliquots $(6.00 \mathrm{~g})$ of mango juice were diluted with $50 \mathrm{~mL}$ distilled water and the TA determined by titration with $0.1 \mathrm{~N}$ sodium hydroxide to an endpoint of $\mathrm{pH}$ 8.2. The TA was expressed as percent citric acid. The SSC of the resulting clear juice samples was determined with a refractometer (Abbe; Cambridge Instruments, Buffalo, NY) and expressed as percent juice fresh weight.

Total ascorbic acid analysis was performed by the dinitrophenylhydrazine method of Terada et al. (1978). Before analysis, $2.5 \mathrm{~g}$ of fresh homogenized mango tissue mixed with $50 \mathrm{~mL}$ of a mixture of $6 \%$ metaphosphoric acid in $2 \mathrm{~N}$ acetic acid was placed into a glass container with an air-tight lid and kept frozen at $-20^{\circ} \mathrm{C}$ until analysis. After thawing, the fruit-acid mixture was centrifuged for $20 \mathrm{~min}$ at $17,600 \mathrm{~g}_{\mathrm{n}}$. The concentration of TAA was calculated from absorbance measured at $540 \mathrm{~nm}$ using a standard curve prepared from a serial dilution of an ascorbic acid standard solution (Sigma-Aldrich, St. Louis, MO). Concentration of ascorbic acid was expressed in terms of fresh weight.

Samples for volatile analysis were prepared by combining $1.5 \mathrm{~g}$ of fresh homogenized mango tissue with $1.5 \mathrm{~g}$ of distilled water in a $10-\mathrm{mL}$ gas chromatography vial, crimp-capped and flash-frozen in liquid nitrogen. The samples were stored at $-20{ }^{\circ} \mathrm{C}$ until analysis. The headspace analysis was conducted using a GC $(6890 \mathrm{~N}$; Agilent, Santa Clara, CA) equipped with a flame ionization detector and a $0.53 \mathrm{~mm} \times 30 \mathrm{~m}, 1.0 \mu \mathrm{m}$ film thickness, polar Stabilwax column. Volatiles were quantified according to Malundo et al. (1997) and Plotto et al. (2006) by using calibration curves determined from enrichment of deodorized mango homogenate with known concentrations of authentic volatile compound standards (Sigma-Aldrich).

Statistical analysis. A completely randomized design was used in this study, comprising the evaluation or analysis of composite samples of eight slices from four replicated containers per treatment (i.e., ripeness stage) and sampling time. Color and firmness measurements were made on 10 and 16 slices, respectively, taken from four replicated containers per treatment and sampling time. The visual evaluation scores were transformed by the arcsine square root method using radians for statistical analysis. Statistical analysis was performed using PC-SAS (version 9.1, SAS Institute). Analysis of variance, using the General Linear Model, was conducted to identify significant main effects because of experiments (Expts. 1 and 2 ), ripeness stages ( $\mathrm{A}, \mathrm{B}$, and $\mathrm{C})$, and storage duration $(0,2,5,7$, and $10 \mathrm{~d})$. Significant differences between treatments were detected using the 
least significant differences test at the $5 \%$ level.

\section{Results}

INITIAL RIPENESS STAGE SELECTION. Initial measurements of the whole mango fruit upon arrival at the laboratory showed that fruit from Expt. 1 were less firm $[62.4 \pm 3.0 \mathrm{~N}( \pm \mathrm{SD})]$ than those from Expt. $2(96.8 \pm 5.8 \mathrm{~N})$ (Fig. 1). Nevertheless, after $\approx 4,6$, and $8 \mathrm{~d}$ at $20{ }^{\circ} \mathrm{C}$, the mangoes in both experiments reached the desired firmness for ripeness stages $\mathrm{A}, \mathrm{B}$, and $\mathrm{C}$, respectively.

Whole fruit firmness was found to be more reliable in selecting three distinct ripeness stages compared with flesh color or SSC. Actually, the fruit firmness at $20{ }^{\circ} \mathrm{C}$ changed in such a way that three distinct firmness classes, statistically different from each other, could be identified (Table 1). This behavior with regard to firmness was identical in both experiments, whereas the SSC and flesh color measurements did not have similar patterns during ripening among the lots. In fact, no significant correlation was found between the firmness of the whole fruit and the flesh color or SSC (data not shown). Moreover, the SSC of mangoes from Expt. 1 was significantly lower than that of fruit from Expt. 2, and the flesh color (hue angle) of the mango slices prepared from the different ripeness stages was not markedly different (Table 1).

SubJECTIVE QUALITY EVALUATION. The subjective quality scores and appearance of mango slices from both experiments decreased consistently during storage regardless of the ripeness stage (Fig. 3). Mango slices from fruit of ripeness stage $\mathrm{A}$ had a shelf life of $10 \mathrm{~d}$ at $5^{\circ} \mathrm{C}$. In both experiments, the visual quality of mango slices was limited by progressive drying of the slice surface and development of off-odor. Moreover, in Expt. 1, the shelf life was also limited by the overall color as mango slices showed a pale discoloration or "bleaching," whereas in Expt. 2, signs of spoilage also limited the product marketability after $10 \mathrm{~d}$ of storage at $5{ }^{\circ} \mathrm{C}$.

The shelf life of mango slices from fruit of ripeness stage $\mathrm{B}$ was $7 \mathrm{~d}$ and was limited by progressive drying of the slice surface and development of off-odor in both

Table 1. Firmness, soluble solids content (SSC), and flesh color (hue angle) of whole 'Kent' mango fruit selected for fresh-cut processing at three different ripeness stages.

\begin{tabular}{lcccc}
\hline Expt. & Ripeness stage & Firmness $(\mathbf{N})^{\mathbf{z}}$ & SSC $(\%)^{\mathbf{y}}$ & Hue angle $\left(\mathbf{h}^{\circ}\right)^{\mathbf{y}}$ \\
\hline Expt. 1 & $\mathrm{A}$ & $36.13 \mathrm{a}^{\mathrm{x}}$ & $15.81 \mathrm{a}$ & $92.26 \mathrm{a}$ \\
& $\mathrm{B}$ & $30.39 \mathrm{~b}$ & $14.37 \mathrm{~b}$ & $90.94 \mathrm{~b}$ \\
& $\mathrm{C}$ & $25.02 \mathrm{c}$ & $14.12 \mathrm{~b}$ & $90.40 \mathrm{~b}$ \\
Expt. 2 & $\mathrm{A}$ & $35.49 \mathrm{a}$ & $18.18 \mathrm{a}$ & $90.47 \mathrm{ab}$ \\
& $\mathrm{B}$ & $30.30 \mathrm{~b}$ & $18.00 \mathrm{a}$ & $90.69 \mathrm{a}$ \\
& $\mathrm{C}$ & $25.01 \mathrm{c}$ & $17.44 \mathrm{a}$ & $89.21 \mathrm{~b}$ \\
\hline
\end{tabular}

${ }^{\mathrm{z}} \mathrm{l} \mathrm{N}=0.2248 \mathrm{lbf}$

${ }^{y}$ Significant difference between the experiments $(P<0.01)$ according to analysis of variance using the general linear model.

${ }^{x}$ Ripeness stages sharing letters within an attribute and within an experiment were not significantly different from each other $(P<0.05)$ according to least significant difference test.

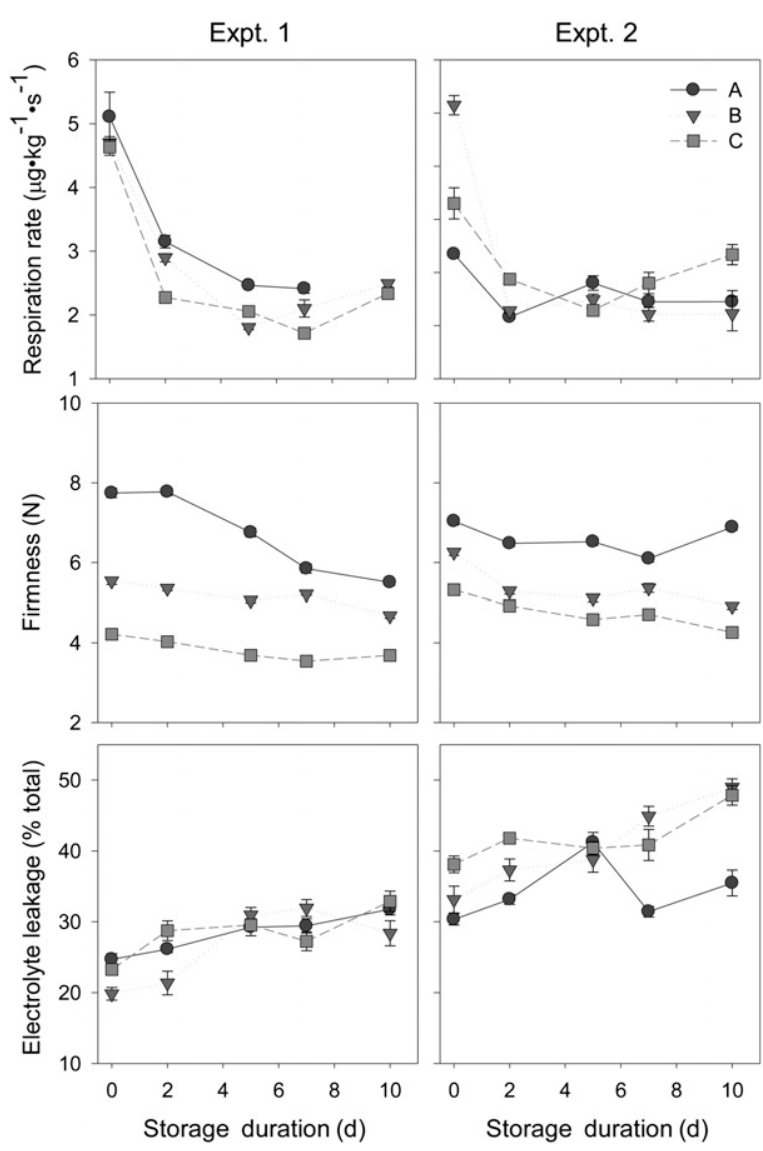

Fig. 4. Changes in respiration rate, firmness, and electrolyte leakage for fresh-cut 'Kent' mango slices during storage at $5^{\circ} \mathrm{C}\left(41.0^{\circ} \mathrm{F}\right)$. The slices were processed from whole fruit at ripeness stages $\mathrm{A}, \mathrm{B}$, or $\mathrm{C}$. Vertical lines at data points represent $\pm \mathrm{SE}$ for $n=4$ (respiration rate and electrolyte leakage) or 16 (firmness); $1 \mathrm{~N}=0.2248 \mathrm{lbf}$.

experiments. Additionally, in Expt. 2 , the shelf life was limited by edge tissue damage, in which the slices became slightly soggy and showed a darker color.

Mango slices from fruit of ripeness stage $\mathrm{C}$ had the shortest shelf life $(5 \mathrm{~d})$. The quality of stage $\mathrm{C}$ slices in both experiments was mainly limited by obvious edge tissue damage as well as slimy surfaces on some of the mango slices (a sign of spoilage). In addition, in Expt. 1, the shelf life of mango slices was limited by darkening of the color, overripe appearance, and development of off-odor. 
Table 2. Analysis of variance table for quality parameters of fresh-cut 'Kent' mango slices at $5{ }^{\circ} \mathrm{C}\left(41.0{ }^{\circ} \mathrm{F}\right)$.

\begin{tabular}{|c|c|c|c|c|c|c|c|c|c|c|}
\hline \multirow{2}{*}{$\begin{array}{l}\text { Source of } \\
\text { variation }^{z}\end{array}$} & \multirow[b]{2}{*}{ df } & \multicolumn{9}{|c|}{ F value } \\
\hline & & $\mathbf{R R}^{\mathbf{y}}$ & Firmness & $E L^{y}$ & Hue angle & Lightness & $\mathrm{pH}$ & $\mathrm{SSC}^{\mathrm{y}}$ & 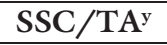 & TAA $^{\mathbf{y}}$ \\
\hline $\mathrm{E}$ & 1 & $1.71 \mathrm{NS}^{\mathrm{x}}$ & $8.66^{* *}$ & $133.92 * * *$ & $4.67^{*}$ & $4.61 \mathrm{NS}$ & $39.33^{* * *}$ & $312.98 * * *$ & $3.76 \mathrm{NS}$ & $38.53^{* * *}$ \\
\hline $\mathrm{D}$ & 4 & $275.47 * * *$ & $10.35^{* * *}$ & $10.80 * * *$ & $23.52 * * *$ & $15.40 * * *$ & $11.18 * * *$ & $0.81 \mathrm{NS}$ & $8.34 * * *$ & $3.42 *$ \\
\hline $\mathrm{E} \times \mathrm{R}$ & 2 & $30.28 * * *$ & $7.04^{* *}$ & $6.94^{* *}$ & $4.83^{* *}$ & 3.75 NS & $214.33 * * *$ & $15.29 * * *$ & $22.98 * * *$ & $5.08 * *$ \\
\hline $\mathrm{E} \times \mathrm{D}$ & 4 & $8.03^{* * *}$ & $1.64 \mathrm{NS}$ & $0.44 \mathrm{NS}$ & $0.81 \mathrm{NS}$ & $1.95 \mathrm{NS}$ & $2.62^{*}$ & 0.57 NS & 1.67 NS & $0.63 \mathrm{NS}$ \\
\hline
\end{tabular}

${ }^{\mathrm{z}}$ Mangoes from both experiments (E) were processed at three ripeness stages (R) and analyzed on days (D) $0,2,5,7$, or 10 during storage.

${ }^{y} \mathrm{RR}=$ respiration rate, $\mathrm{EL}=$ electrolyte leakage, $\mathrm{SSC}=$ soluble solids content, $\mathrm{TA}=$ titratable acidity, $\mathrm{TAA}=$ total ascorbic acid.

${ }^{\mathrm{x}}$ Significant $\mathrm{F}$ values indicated by Ns, ${ }^{*},{ }^{* *}$, or ${ }^{* * *}=$ nonsignificant or significant at $P<0.05,0.01$, or 0.001 , respectively, according to analysis of variance; NS $=$ nonsignificant.

Respiration Rate. Overall, the RR of mango slices was not different among the ripeness stages and between experiments (Table 2). However, the RR decreased during storage with the highest rate measured on day 0 and the lowest on days 5 and 7 (Fig. 4).

The significant interaction between (experiments $\times$ ripeness stages) (Table 2) was due to higher RR measured in slices from ripeness stages $\mathrm{A}$ and $\mathrm{C}$ in Expt. 1 compared with Expt. 2, whereas slices of ripeness stage $B$ had lower RR in Expt. I compared with Expt. 2. Moreover, the significant interaction (experiments $\times$ storage days) resulted from the overall higher initial RR (on days 0 and 2) in Expt. I compared with Expt. 2 (all ripeness stages included), whereas for the rest of the storage duration, Expt. 2 had in general higher RR than Expt. 1 (Table 2). Also, the interaction (ripeness stages $\times$ storage days) indicates that the RR of freshcut mango slices from the different ripeness stages varied during storage. On day 0 , higher RR were measured in stage B slices in Expt. 2 compared with stages $\mathrm{C}$ and $\mathrm{A}$ (lowest RR), whereas for days 5,7 , and 10 , stage $B$ mango slices had lower RR compared with stage A.

FIrmness. The overall firmness of mango slices was higher in Expt. 2 than in Expt. 1, and slices from ripeness stage A were significantly firmer than those from stages $\mathrm{B}$ and $\mathrm{C}$ (Table 2). The firmness of the mango slices declined during storage at $5{ }^{\circ} \mathrm{C}$ while the firmness differences between the ripeness stages were maintained (Table 2; Fig. 4). Firmness slightly decreased from days 0 to 5 in slices from all ripeness stages and then remained quite constant for the rest of the storage duration. There was a significant interaction between experiment and

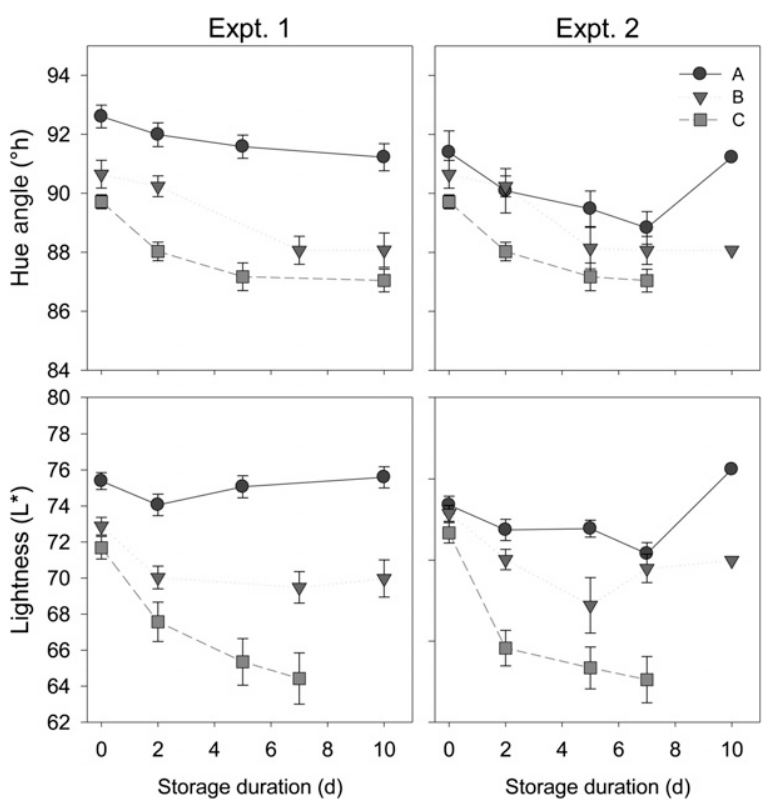

Fig. 5. Changes in the flesh color (hue angle and lightness) in fresh-cut 'Kent' mango slices during storage at $5^{\circ} \mathrm{C}\left(40.0^{\circ} \mathrm{F}\right)$. The slices were processed from whole fruit at ripeness stages $\mathrm{A}, \mathrm{B}$, or $\mathrm{C}$. Vertical lines at data points represent $\pm \mathrm{SE}$ for $n=10$.

ripeness stage (Table 2) that can be explained by the fact that the firmness of slices from ripeness stages $\mathrm{B}$ and $\mathrm{C}$ was higher in Expt. 2 than Expt. 1, but slices from ripeness stage A were firmer in Expt. 1 than in Expt. 2.

Electrolyte Leakage. There were significant changes in EL related to experiment, ripeness stage, and storage duration (Table 2). No significant difference in EL levels was measured in Expt. 1 among the ripeness stages. But in Expt. 2, a higher or equal level of EL was measured in slices from ripeness stage $\mathrm{C}$ compared with slices of stage $B$, which had higher levels than slices of stage $\mathrm{A}$ (i.e., $\mathrm{C} \geq \mathrm{B}>\mathrm{A}$ ). In general, there was a significant effect of storage duration on EL (Table 2), with the EL increasing $\approx 50 \%$ during the $10 \mathrm{~d}$ of storage (Fig. 4).
FLESH COLOR. Mango slices from ripeness stage A were significantly yellower than slices from ripeness stages $\mathrm{B}$ and $\mathrm{C}$ as characterized by a higher hue angle value (Table 2 ). In general, the hue angle of mango slices decreased during storage at $5{ }^{\circ} \mathrm{C}$ (Table 2; Fig. 5). The significant interaction between (experiments $\times$ ripeness stages) is explained by the higher hue angle value of the slices of ripeness stage A in Expt. 1 compared with Expt. 2, whereas similar hues were measured for stages $\mathrm{B}$ and $\mathrm{C}$ among the experiments (Table 2). Moreover, during storage, slices from mangoes of ripeness stages $\mathrm{A}, \mathrm{B}$, and $\mathrm{C}$ maintained distinctly different hue values, with the exception of day 2 (Expt. 2) where slices of ripeness stages A and B had similar hues, explaining the significant interaction 
(ripeness stage $\times$ storage duration) (Table 2).

During storage, the lightness $\left(L^{*}\right.$ value) of mango slices varied significantly between the ripeness stages (Table 2). In fact, slices of ripeness stage $\mathrm{C}$ showed a rapid decrease in $L^{*}$ value during storage compared with the other ripeness stages (Fig. 5). However, the $L^{*}$ value of slices from ripeness stage $B$ remained constant throughout storage, whereas in Expt. 2, slices from ripeness stage A showed a slight increase in lightness after $7 \mathrm{~d}$, which was associated with the bleaching effect observed during the visual subjective evaluations (Fig. 5 ).

Fruit composition. The mango slices of ripeness stage $A$ had higher pH in Expt. 2 than in Expt. 1, whereas for the other stages, the $\mathrm{pH}$ was higher in Expt. 1 than in Expt. 2, explaining the significant interaction (experiments $\times$ ripeness stages) (Table 2). There was a significant effect of storage duration on $\mathrm{pH}$ (Table 2) since, as ripening progressed, the $\mathrm{pH}$ of the mango slices slightly increased (Fig. 6). There was also a significant effect of ripeness stage on $\mathrm{pH}$ (Table 2) as slices of ripeness stage $\mathrm{A}$ had the lowest $\mathrm{pH}$ and stage $\mathrm{C}$ the highest. Larger differences in $\mathrm{pH}$ within ripeness stages were observed in Expt. 1 compared with Expt. 2.

In this study, SSC was significantly higher in Expt. 2 compared with Expt. 1 (Table 2; Fig. 6). Overall, the SSC did not change during storage, and SSC of slices of ripeness stage A in Expt. I was significantly higher than SSC of slices from ripeness stages $\mathrm{B}$ and $\mathrm{C}$.

The SSC:TA ratio varied significantly between ripeness stages (Table 2; Fig. 6) with slices from ripeness stage B having lower SSC:TA than slices from ripeness stage $\mathrm{C}$, whereas those from stage $A$ had an even lower SSC:TA ratio. The SSC:TA ratio also varied significantly with storage duration, with the SSC:TA of all ripeness stages tending to increase during storage as the TA declined, whereas the SSC changed little, indicating that organic acids were probably preferentially used as substrates for respiration.

Total ascorbic acid content increased during storage and was higher in mango slices from Expt. 2 compared with Expt. 1 (Table 2; Fig. 6). However, when the two experiments
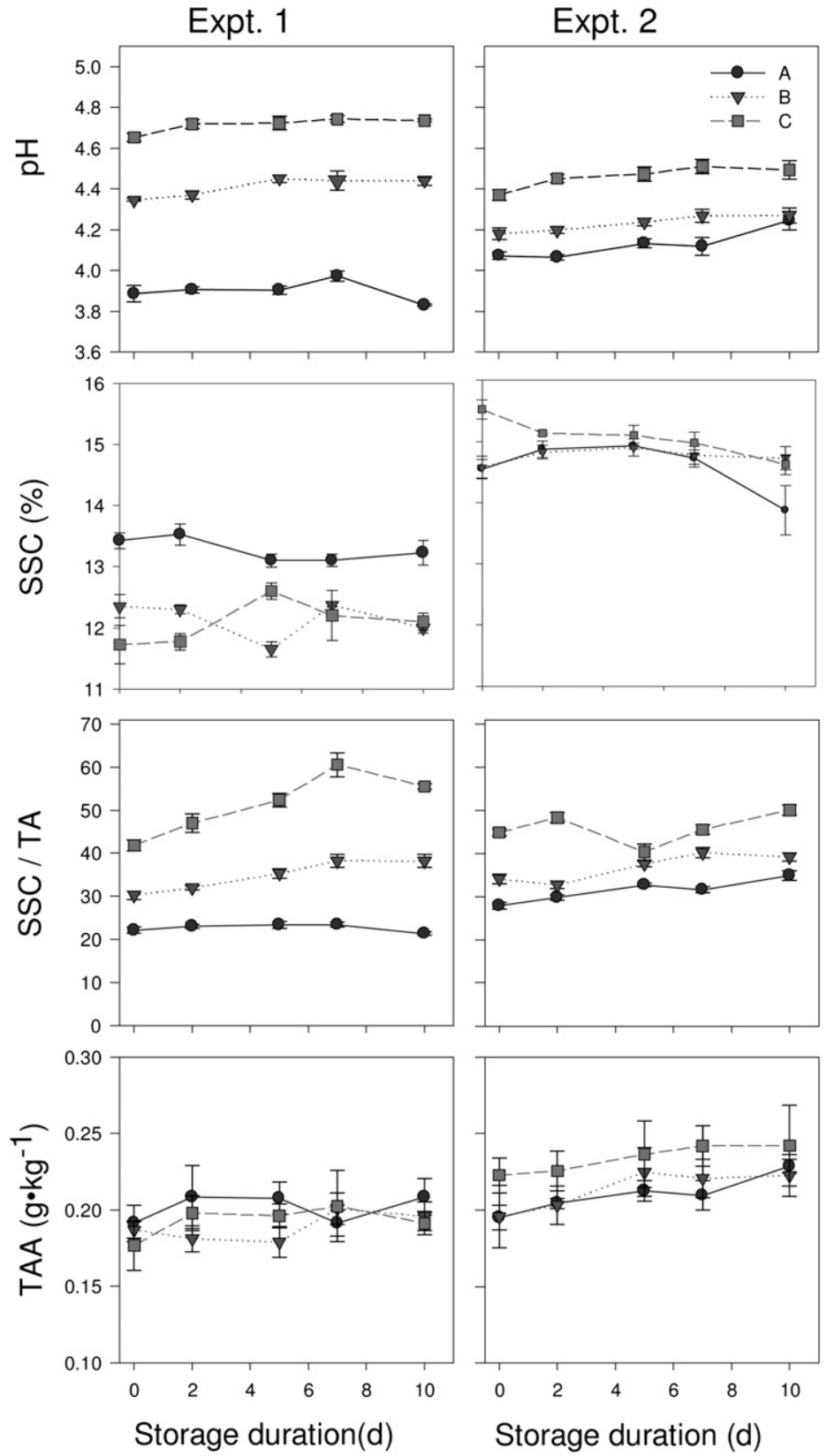

Fig. 6. Changes in the pH, soluble solids content (SSC), SSC:titratable acidity (TA) ratio, and total ascorbic acid (TAA) in fresh-cut 'Kent' mango slices during storage at $5{ }^{\circ} \mathrm{C}\left(41.0^{\circ} \mathrm{F}\right)$. The slices were processed from whole fruit at ripeness stages $\mathrm{A}, \mathrm{B}$, or C. Vertical lines at data points represent \pm SE for $n=4 ; 1 \mathrm{~g} \cdot \mathrm{kg}^{-1}=0.1 \%$.

were analyzed separately, no significant effect of ripeness stage or storage duration was observed in Expt. 1, whereas in Expt. 2, slices from ripeness stage $C$ had overall significantly higher TAA compared with slices from ripeness stages $\mathrm{A}$ and $\mathrm{B}$. Moreover, in Expt. 2, only the slices from ripeness stage A showed a slight increase in TAA during storage at $5^{\circ} \mathrm{C}$, whereas no significant change in TAA was observed in the slices from riper fruit (stage C).
Overall, no significant differences between experiments, ripeness stages, or storage durations were observed for methanol, limonene, $\rho$-cymene, and caryophyllene (data not shown). The changes in volatile content for all of the volatiles that were affected by one or more of the main effects evaluated in this study during storage at $5{ }^{\circ} \mathrm{C}$ are presented in Figs. 7-10.

Higher contents of hexanal, acetone, 3-carene, and ethyl acetate were measured in Expt. 1, whereas higher 

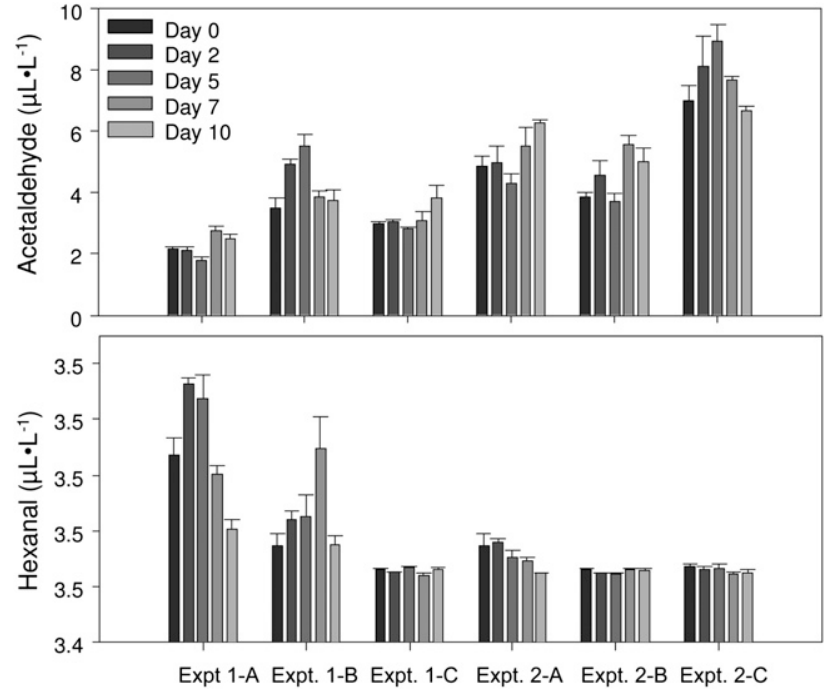

Fig. 7. Changes in acetaldehyde and hexanal in fresh-cut 'Kent' mango slices during storage at $5^{\circ} \mathrm{C}\left(41.0^{\circ} \mathrm{F}\right)$. The slices were processed from whole fruit at ripeness stages $A, B$, or $C$ for Expts. 1 and 2 . Vertical lines represent SE for $n=4 ; 1 \mu \mathrm{L} \cdot \mathrm{L}^{-1}=$ 1 ppm.

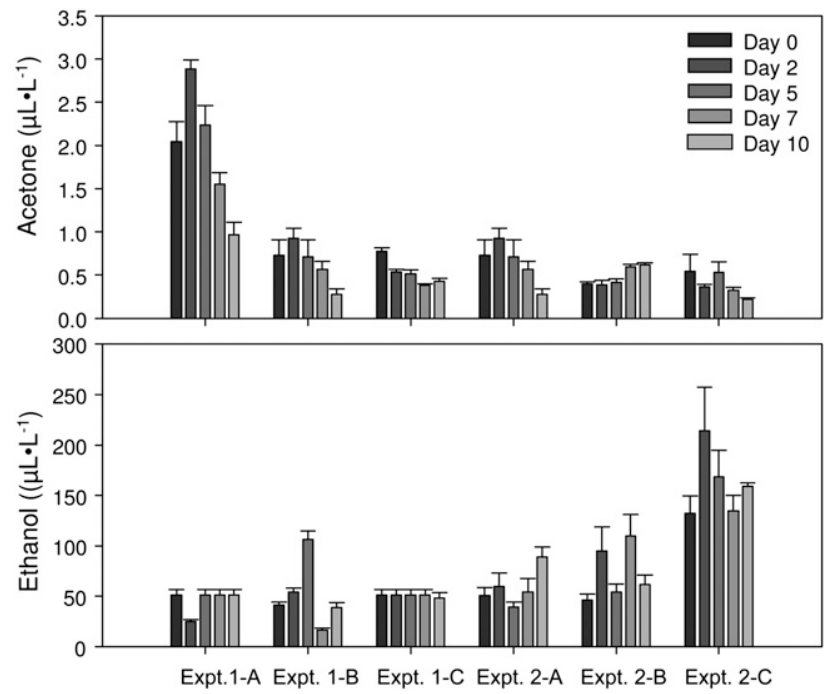

Fig. 8. Changes in acetone and ethanol in fresh-cut 'Kent' mango slices during storage at $5{ }^{\circ} \mathrm{C}\left(41.0^{\circ} \mathrm{F}\right)$. The slices were processed from whole fruit at ripeness stages $\mathrm{A}, \mathrm{B}$, or $\mathrm{C}$ for Expts. 1 and 2 . Vertical lines represent SE for $n=4 ; 1 \mu \mathrm{L} \cdot \mathrm{L}^{-1}=1 \mathrm{ppm}$.

contents of acetaldehyde, ethanol, $\alpha$-pinene, myrcene, and $\alpha$-terpinolene were measured in Expt. 2. Mango ripeness stage had a significant effect on the concentration of most of the volatiles measured (Table 3 ). Ripeness stage $\mathrm{A}$ had higher contents of hexanal, acetone, $\alpha$-pinene, 3 -carene, $\alpha$-copaene, ethyl butyrate, and ethyl acetate compared with similar lower levels for stages B and C. Acetaldehyde content increased with ripening, with higher levels found in ripeness stage $\mathrm{C}$ and the lowest in A. Ethanol content was highest in ripeness stage $\mathrm{C}$ and was at comparable lower levels in $\mathrm{A}$ and B. Higher concentrations of $\alpha$-terpinolene were measured in slices of ripeness stages $B$ and $C$ than in stage A. Moreover, the concentrations of $\alpha$-pinene and myrcene were higher in ripeness stage $\mathrm{B}$ and lower in stage $\mathrm{A}$.

The storage duration also affected the concentration of some volatiles (Table 3 ). Overall, acetaldehyde and ethanol increased during storage at $5{ }^{\circ} \mathrm{C}$, whereas hexanal, acetone, and ethyl butyrate were significantly lower on day 10 than earlier in storage. The content of $\alpha$-copaene decreased in Expt. 1 from day 0 to day 2 but remained constant thereafter, whereas lower $\alpha$-copaene was measured in Expt. 2 on day 2.

\section{Discussion}

INITIAL RIPENESS STAGE SELECTION. Whole fruit firmness was preferred over SSC and flesh color (hue angle) for the selection of mangoes for fresh-cut processing because of its consistency and reliability as a measurement to select distinct ripeness stages among the different lots of fruit. Previous studies have suggested that SSC, alone or in combination with flesh firmness, was the best method to establish the initial ripeness stage for processing fresh-cut mangoes (Allong et al., 2000; Beaulieu and Lea, 2003). However, in this study, a significant difference in the SSC and in the hue angle of fruit from the two different sources was observed, whereas little or no significant difference in the SSC was measured between the different ripeness stages identified based on fruit firmness (Table 1). The difference in the SSC and hue angle between experiments may be attributable to the different origin of each fruit lot. In fact, it is known that fruit quality and composition varies greatly among different origins and cultivation practices (Kays and Paull, 2004). Moreover, the higher SSC content measured in mango slices of ripeness stage $\mathrm{A}$ in Expt. 1 may be attributable to the fact that when extracting the juice from the peel side excised from the fruit, cell residues and potentially residual starch may have influenced and increased the SSC measurements.

Moreover, in the case of 'Kent' mangoes, the change in the ground color of the peel is not a reliable ripeness stage indicator since the 'Kent' is known to not change extensively in peel color during ripening. Therefore, it was more accurate to use nondestructive whole fruit firmness measurements as a way to select a uniform fruit sample from different batches rather than to select ripeness stages based on SSC or flesh or peel color. However, this conclusion does not argue against the importance for fresh-cut processors to set minimum SSC and flesh color requirements for 

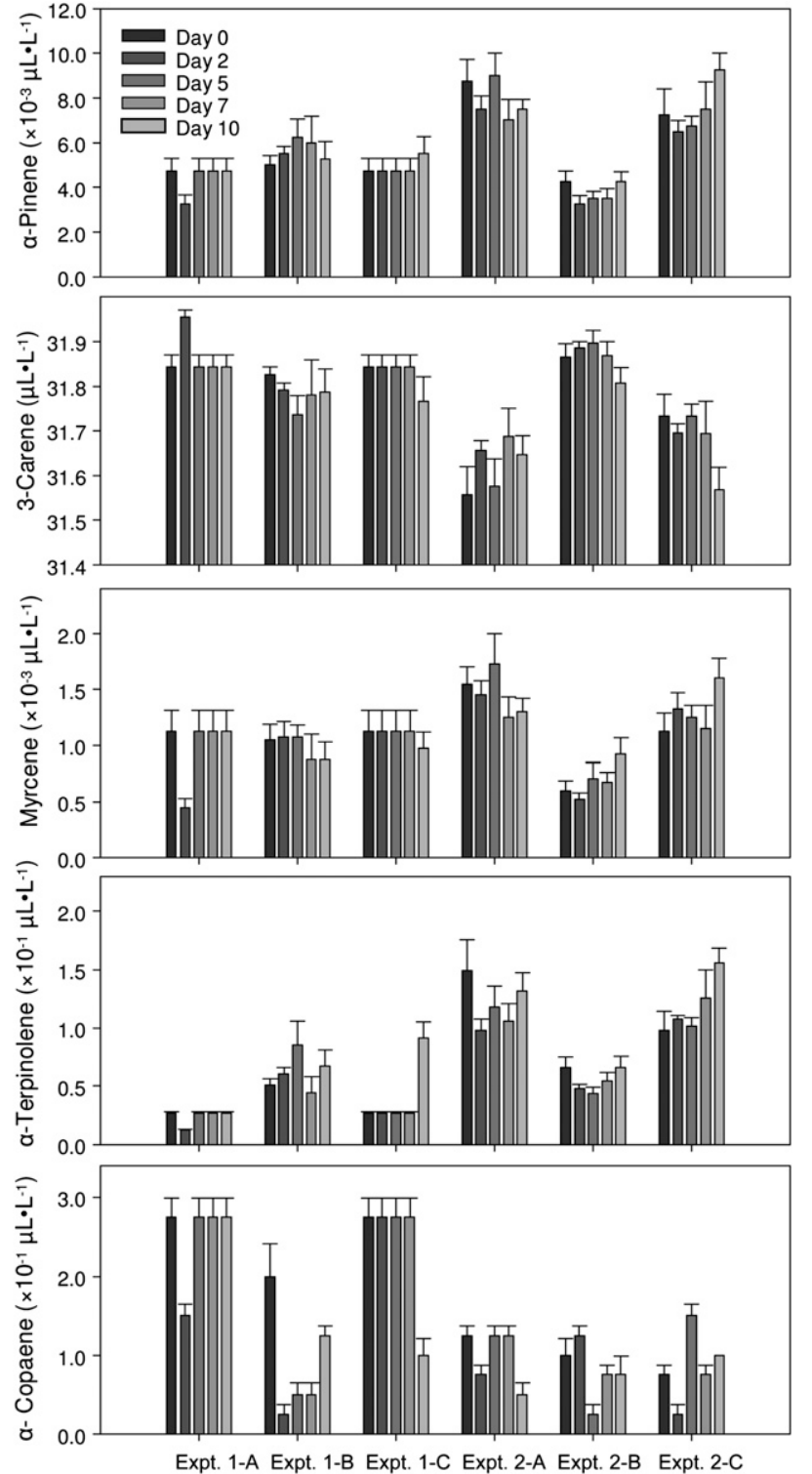

Fig. 9. Changes in selected terpenes in fresh-cut 'Kent' mango slices during storage at $5{ }^{\circ} \mathrm{C}\left(41.0^{\circ} \mathrm{F}\right)$. The slices were processed from whole fruit at ripeness stages $\mathrm{A}, \mathrm{B}$, or $\mathrm{C}$ for Expts. 1 and 2. Vertical lines represent SE for $n=4 ; 1 \mu \mathrm{L} \cdot \mathrm{L}^{-1}=1 \mathrm{ppm}$.

mango lots to be considered acceptable for fresh-cut processing.

RIPENESS STAGES AND FRESH-CUT QUALITY. The ripeness stage of the whole fruit before processing into slices had a significant effect on the shelf life of the fresh-cut mango slices. For mango slices of ripeness stages $A$ and $B$, the visual quality was limited by progressive drying of the surface and detectable off-odor, whereas for slices from fruit of ripeness stage $\mathrm{C}$, texture became softer and led rapidly to obvious edge damage and spoilage. Therefore, the shelf life was limited to 10,7 , and $5 \mathrm{~d}$ for ripeness stages $\mathrm{A}, \mathrm{B}$, and $\mathrm{C}$, respectively. Similar results were previously reported by Beaulieu and Lea (2003) who showed that the shelf life of soft-ripe 'Keitt' and 'Palmer' mango cubes was limited by poor texture and mushy tissue, followed by loss of aroma and general discoloration, whereas the shelf life of firm-ripe cubes was limited by development of off-odor and desiccation. Gorny et al. (1999) also reported shorter shelf life based on visual quality for overripe fresh-cut peaches and nectarines (Prunus persica) than for less ripe fruit, with the overripe fruit developing darker color and retaining less visible structural integrity and general visual appeal than mature-green fruit.

The initial ripeness stage of the fruit used for fresh-cut processing is a critical factor as it may impact several metabolic and physiologic activities such as RR and ethylene production, and consequently changes the overall quality of the fresh-cut product, such as changes in appearance, color, and texture (Soliva-Fortuny et al., 2004). However, in this study, the initial ripeness stage of the whole fruit had no significant effect on the RR of the fresh-cut mango slices. All treatments showed high RR on day 0 , probably because of the wound response, but the RR decreased significantly by day 2 , remaining constant for the rest of shelf life period for each maturity stage. These results are in agreement with those reported by Allong et al. (2001), in which a significant decrease in RR was measured for firm-ripe and soft-ripe 'Julie' and 'Graham' mango slices after $12 \mathrm{~h}$ of storage at $5^{\circ} \mathrm{C}$ and the $R R$ remained steady for the rest of the storage duration. The RR increased in the riper slices for measurements that were made beyond the end of shelf life (Fig. 4). Although no samples with visible decay were used for respiration measurements, it is possible that the presence of microorganisms that were not visible could have influenced those later respiration measurements.

The initial slice firmness was significantly different between the ripeness stages with less ripe slices being firmer than the more ripe. The EL increased with ripening, which parallels the changes in cell membrane integrity and permeability that occur as a result of fruit ripening and tissue injury (Nyanjage et al., 1999). The flesh color also varied with the stage of fruit ripeness. Slices from stage C fruit (i.e., more ripe) had a more yellow-orange color than the less ripe fruit (A and B), probably because of increased carotenoid content as the fruit ripened (Moore, 2003; Yashoda et al., 2006). The "bleaching" effect observed on the slices of ripeness stage A may be attributable to surface desiccation (Watada and Qi, 1999). Besides, because the slices from fruit of ripeness stage A were not initially as juicy as the slices from the other, more advanced, ripeness stages, they lost their glossiness and color more rapidly. 

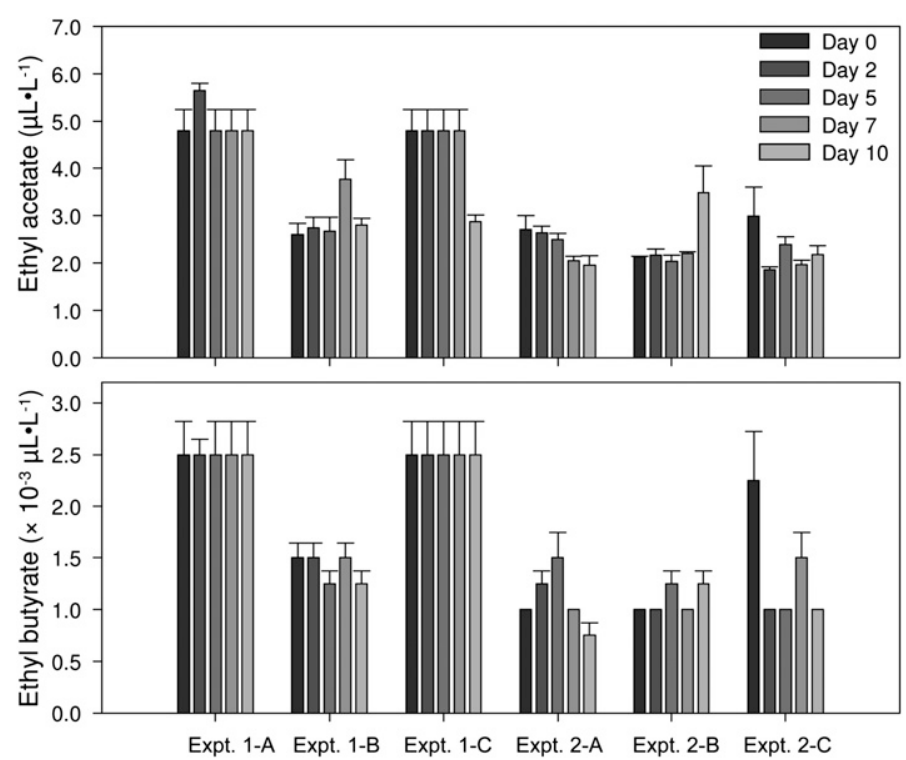

Fig. 10. Changes in esters in fresh-cut 'Kent' mango slices during storage at $5{ }^{\circ} \mathrm{C}$ $\left(41.0^{\circ} \mathrm{F}\right)$. The slices were processed from whole fruit at ripeness stages $\mathrm{A}, \mathrm{B}$, or $\mathrm{C}$ for Expts. 1 and 2. Vertical lines represent sE; $1 \mu \mathrm{L} \cdot \mathrm{L}^{-1}=1 \mathrm{ppm}$.

As previously reported by others (Allong et al., 2000; Medlicott and Thompson, 1985; Sharaf et al., 1989), and in this study, the $\mathrm{pH}$ and the SSC:TA ratio of the mango slices also increased with ripening, which suggests that mango slices processed at ripeness stage $\mathrm{C}$, with higher SSC:TA ratio and higher $\mathrm{pH}$, would be perceived as sweeter than slices from ripeness stage $\mathrm{A}$ and thus, would initially have a more desirable eating quality. The lack of significance between experiments and ripeness stages regarding TAA measurements suggests that this parameter is not suitable for mango ripeness stage differentiation.

RIPENESS STAGES AND AROMA volATILES. Initial aroma volatile differences were observed between the experiments (Expts. 1 and 2). On day 0 , the amount of acetaldehyde, ethanol, $\alpha$-pinene, $\alpha$-terpinolene, and limonene were higher in fruit from Expt. 2 than from Expt. 1 (Figs. 7-9). When those volatiles were analyzed within each experiment, only acetaldehyde (Fig. 7) and $\alpha$-terpinolene (Fig. 9) showed a significant difference between the different ripeness stages. In fact, in both experiments, higher acetaldehyde content was measured in slices from fruit of ripeness stage $\mathrm{C}$ than in slices from other stages. Conversely, in Expt. 1, $\alpha$-terpinolene concentration was significantly lower in slices from fruit of ripeness stage
A than in stages B and C, whereas in Expt. 2 no significant differences were observed in the $\alpha$-terpinolene content.

Overall, slices of mango from ripeness stage $\mathrm{A}$ had higher contents of acetone, 3-carene, and ethyl acetate. Slices from fruit of ripeness stage $\mathrm{C}$ showed the highest content of ethanol and acetaldehyde. Slices from ripeness stage $B$ had an intermediate concentration of acetaldehyde and hexanal compared with stages $\mathrm{A}$ and $\mathrm{C}$, similar concentration of ethanol as A, similar content of ketones and esters as $\mathrm{C}$, and lower or equal amount of the terpenes measured than ripeness stage C. These results are in accordance with the findings published by Beaulieu and Lea (2003) that cubes from softripe mangoes had higher content of ethanol and aldehydes than firmripe cubes, which, in contrast, had the highest content of terpenes, with 3 -carene being the dominant aroma volatile.

Aroma volatile compounds are the major constituents of fruit aroma, which in turn have a great influence on consumer perception and preference, and are therefore important in defining fruit quality. In this study, the high content of acetone and the terpenes measured, combined with the lower $\mathrm{pH}$ and SSC:TA ratio, may have given the mango slices of ripeness stage $\mathrm{A}$ a more acidic, green, and piney flavor compared with the other stages (Beaulieu and Lea, 2003). However, even if the slices processed at ripeness stage $\mathrm{C}$ may have been perceived as tasting sweeter and less acidic than the other ripeness stages, the high ethanol and acetaldehyde contents that accumulated during storage may lead to a fermented aroma that might not be appealing to consumers. Therefore, it is likely that slices processed from fruit of ripeness stage $B$, which had lower terpene content than slices processed at ripeness stage $\mathrm{A}$ and lower alcohol content than ripeness stage $\mathrm{C}$, along with an intermediate SSC:TA ratio, would possess the best aroma to reflect the optimal eating quality of 'Kent' mango fruit. Taste panel tests should be performed to investigate this assumption.

This study determined the optimal initial ripeness stage of the whole fruit for processing 'Kent' mangoes into fresh-cut slices. Selection of the initial ripeness stage was based on whole fruit firmness, which was more reliable than the use of flesh color or SSC since the latter two attributes varied much less among the fruit in each experiment than did firmness. The maximum shelf life based on subjective visual evaluation was 10 , 7 , and $5 \mathrm{~d}$ for ripeness stages $\mathrm{A}(35$ $\mathrm{N}), \mathrm{B}(30 \mathrm{~N})$, and $\mathrm{C}(25 \mathrm{~N})$, respectively. Additional testing will be necessary to determine if these results can be extended to other mango cultivars.

Appearance and freshness are critical for the consumer's decision to buy the product at the store, but it is the overall sensory experience (texture, flavor, and aroma) that will guarantee product success and a subsequent purchase. Therefore, a ripeness stage equal to an initial firmness of $30 \mathrm{~N}$ would be the recommended ripeness stage for processing 'Kent' mangoes into fresh-cut slices to assure maintenance of the best possible overall quality and maximum shelf life under refrigerated conditions. At a ripeness stage equivalent to a firmness of $30 \mathrm{~N}$, a maximum shelf life of $7 \mathrm{~d}$ at $5^{\circ} \mathrm{C}$ can be expected without the addition of any food additive, such as an antioxidant or edible coating. Moreover, the product would have intermediate firmness, $\mathrm{pH}$, and SSC:TA ratio and a well-balanced aroma volatile 
profile. It is noteworthy that this study should be conducted with other cultivars to confirm the results reported since each mango cultivar has its own ripening characteristics.

\section{Literature cited}

Allong, R., L.D. Wickham, and M. Mohammed. 2000. The effect of cultivar, fruit ripeness, storage temperature and duration on quality of fresh-cut mango. Acta Hort. 509:487-494.

Allong, R., L.D. Wickham, and M. Mohammed. 2001. Effect of slicing on the rate of respiration, ethylene production and ripening of mango fruit. J. Food Qual. 24:405-419.

Beaulieu, J.C. and J.R. Gorny. 2004. Fresh-cut fruit. In: K.C. Gross, C.Y. Wang, and M. Saltveit (eds.). The commercial storage of fruits, vegetables and florist and nursery stocks. Agr. Hdbk. No. 66. 26 Oct. 2012. <http://www.ba.ars. usda.gov $/ \mathrm{hb} 66 />$.

Beaulieu, J.C. and J.M. Lea. 2003. Volatile and quality changes in fresh-cut mangos prepared from firm-ripe and soft-ripe fruit, stored in clamshell containers and passive MAP. Postharvest Biol. Technol. 30:15-28.

Beirão-da-Costa, S., A. Steiner, L. Correia, J. Empis, and M. Moldão-Martins. 2006. Effects of maturity stage and mild heat treatments on quality of minimally processed kiwifruit. J. Food Eng. 76:616625 .

Brecht, J.K. 1995. Physiology of lightly processed fruits and vegetables. HortScience 30:18-22.

Brecht, J.K., M.E. Saltveit, S.T. Talcott, K.R. Schneider, K. Felkey, and J.A. Bartz. 2004. Fresh-cut vegetables and fruit. Hort. Rev. 30:185-251.

Francis, F.J. 1980. Color quality evaluation of horticultural crops. HortScience $15: 58-59$.

Gil, M.I., E. Aguayo, and A.A. Kader. 2006. Quality changes and nutrient retention in fresh-cut versus whole fruits during storage. J. Agr. Food Chem. 54:4284-4296.

González-Aguilar, G.A., J. Celis, R.R. Sotelo-Mondo, L.A. Rosa, J. RodrigoGarcia, and E. Alvarez-Parrilla. 2007. Physiological and biochemical changes of different fresh-cut mango cultivars stored at $5{ }^{\circ} \mathrm{C}$. Intl. J. Food Sci. Technol. 43:91-101.

Gorny, J.R., R.A. Cifuentes, B. HessPierce, and A.A. Kader. 2000. Quality changes in fresh-cut pear slices as affected by cultivar, ripeness stage, fruit size, and storage regime. J. Food Sci. 65:541-544.

Gorny, J.R., B. Hess-Pierce, and A.A. Kader. 1999. Postharvest physiology and quality maintenance of fresh-cut nectarines and peaches. Acta Hort. 485:173179.

Hodges, D.M. and P.M.A. Toivonen. 2008. Quality of fresh-cut fruits and vegetables as affected by exposure to abiotic stress. Postharvest Biol. Technol. 48:155-162.

Kays, S.J. and R.E. Paull. 2004. Postharvest biology. Exon Press, Athens, GA.

Malundo, T.M.M., E.A. Baldwin, M.G. Moshonas, R.A. Baker, and R.L. Shewfelt. 1997. Method for the rapid headspace analysis of mango (Mangifera indica L.) homogenate volatile constituents and factors affecting quantitative results. J. Agr. Food Chem. 45:2187-2194.

Medlicott, A.P. and A.K. Thompson. 1985. Analysis of sugars and organic acids in ripening mango fruits (Mangifera indica L. var. Keitt) by high performance liquid chromatography. Sci. Food Agr. 36:561-566

Moore, J.P. 2003. Carotenoid synthesis and retention in mango (Mangifera ind$i c a)$ fruit and puree as influenced by postharvest and processing treatment. Univ. Florida, Gainesville, Master's Thesis.

Nyanjage, M.O., H. Wainwright, and C.F.H. Bishop. 1999. Effects of hotwater treatment and storage temperature on electrolyte leakage of mangoes (Mangifera indica Linn.). J. Hort. Sci. Biotechnol. 74:566-572.

Plotto, A., J. Bai, J.A. Narciso, J.K. Brecht, and E.A. Baldwin. 2006. Ethanol vapor prior to processing extends freshcut mango storage by decreasing spoilage, but does not always delay ripening. Postharvest Biol. Technol. 39:134-145.

Rico, D., A.B. Martín-Diana, J.M. Barat, and C. Barry-Ryan. 2007. Extending and measuring the quality of fresh-cut fruit and vegetables: A review. Trends Food Sci. Technol. 18:373-386.

Rivera-López, J., F.A. Vázquez-Ortiz, F. Ayala-Zavala, R.R. Sotelo-Mundo, and G.A. González-Aguilar. 2005. Cutting shape and storage temperature affect overall quality of fresh-cut papaya cv. 'Maradol'. J. Food Sci. 70:482-489.

Sharaf, A., F.A. Ahmed, and S.S. ElSaadany. 1989. Biochemical changes in some fruits at different ripening stages. Food Chem. 31:19-28.

Soliva-Fortuny, R.C., P. Elez-Martínez, and O. Martín-Belloso. 2004. Microbiological and biochemical stability of fresh-cut 
apples preserved by modified atmosphere packaging. Innov. Food Sci. Emerg. Technol. 5:215-224.

Soliva-Fortuny, R.C. and O. MartínBelloso. 2003. New advances in extending the shelf life of fresh-cut fruits: A review. Trends Food Sci. Technol. 14:341-353.

Terada, M., Y. Watanabe, M. Kunitomo, and E. Hayashi. 1978. Differential rapid analysis of ascorbic acid 2-sulfate by dinitrophenylhydrazine method. Anal. Biochem. 84:604-608.

Tovar, B., H.S. Garcia, and M. Mata. 2001. Physiology of pre-cut mango. I. ACC and ACC oxidase activity of slices subjected to osmotic dehydration. Food Res. Intl. 34:207-215.
Watada, A.E. and L. Qi. 1999. Quality of fresh-cut produce. Postharvest Biol. Technol. 15:201-205.

Yashoda, H.M., T.M. Prabha, and R.N. Tharanathan. 2006. Mango ripening: Chemical and structural characterization of pectic and hemicellulosic polysaccharides. Carbohydr. Res. 340:1335-1342. 